\title{
ОСОБЛИВОСТІ ДИСТАНЦІЙНОГО НАВЧАННЯ ГРИ НА МУЗИЧНОМУ ІНСТРУМЕНТІ СТУДЕНТІВ ЗВО
}

\author{
Сергій Чугай \\ старший викладач кафедри музики і хореографії \\ ДВНЗ «Донбаський державний педагогічний університет» \\ м. Слов'янськ, Україна \\ ORCID ID 0000-0003-4294-888X \\ sergeichugay@gmail.com
}

\begin{abstract}
Анотація. У статті розглянуто нові можливості та підходи в організації дистанційного навчання, методи дистанційного навчання та ефективність їх використання у процесі гри на музичному інструменті. Висвітлено можливості дистанційного навчання в системі професійної підготовки. Розкрито теоретичні аспекти розвитку дистанційної освіти. Розглянуто особливості використання дистанційних технологій, які входять у практику сучасного освітнього процесу.

Визначено форми, методи роботи, які використовуються при дистанційному навчанні. Здійснено аналіз переваг та недоліків дистанційного навчання під час гри на музичному інструменті. Досліджено проблему формування самостійності студентів ЗВО під час дистанційного навчання грі на музичному інструменті. Проаналізовано значення формування самостійності студентів в процесі фахового навчання. Визначено, що самостійність студентів $\epsilon$ складною професійно-особистісною властивістю, яка виникає на грунті засвоєння спеціальних (мистецьких) та психолого-педагогічних знань, втілюється в широкий спектр практичних умінь та навичок, спонукає до активних дій. Обгрунтовано організаційнопедагогічні умови формування самостійності студентів в процесі дистанційного навчання.

Ключові слова: дистанційне навчання; музичне навчання; дистанційні технології; музичне мистецтво; музичний інструмент; самостійна робота; студент; здобувач вищої освіти.
\end{abstract}

Постановка проблеми в загальному вигляді. Україна є невід’ємною частиною світового освітнього простору, що стрімко змінюється й оновлюється в умовах глобалізації, інформаційної технологізації та універсалізації суспільних відносин. Суспільні очікування пов'язуються 3 якісним оновленням системи вищої педагогічної освіти. Саме сьогодні гостро відчувається потреба в педагогах-фахівцях, які мають високий загальнокультурний рівень, здатні оволодіти сучасним педагогічним інструментарієм не тільки спираючись на засвоєний зміст основних навчальних курсів, а й за допомогою вмінь віднайти самостійно потрібну для навчання й професійного становлення інформацію, навчитися сприймати іiі автономно й дистанційно, застосувавши власні можливості до самоформатування та структурування потрібного навчального матеріалу (Дубовий, 2019).

У період сучасних викликів суспільства, пов'язаних з пандемією (20192021 н.р.), актуальною перед 3ВО постає проблема швидкого реагування й 


\section{С. ЧУГАЙ}

Особливості дистанційного навчання гри на музичному інструменті студентів ЗВО

безболісного переходу від навчання, що поєднує у собі як традиційні так i дистанційні технології (змішаного навчання) до дистанційного навчання без втрати якості освітнього процесу (Смаковський, 2020).

Аналіз останніх досліджень і публікацій. Дистанційне навчання розглядається у сучасних нормативних документах, зокрема в Законі України «Про освіту» (Закон України про освіту, 2017) та «Положенні про дистанційне навчання» (Положення про дистанційне навчання, 2013). Ці документи розкривають основні засади, особливості організації освітнього процесу 3 використанням технологій дистанційного навчання (Дорош, 2021).

Методологічні основи дистанційного навчання визначені працями таких учених, як С. Атанасян, В. Биков, Р. Гуревич, Т. Дорош, Н. Морзе, Н. Панаріна, Є. Полат; педагогічні аспекти відкритого дистанційного середовища досліджують Л. Гаврілова (2019), О. Андреєв, В. Беспалько, О. Коломієць, В. Кухаренко. Особливості процесу професійної підготовки майбутніх педагогів мистецьких спеціальностей висвітлено в доробку таких учених, як Л. Гаврілова, М. Лещенко, Л. Масол, В. Орлов, О. Отич, О. Ростовський, О. Рудницька, О. Стукалова, С. Шаргородська, а власне майбутніх учителів музики у працях Ю. Азарова, А. Болгарського, В. Гури, А. Зайцевої, Р. Савченко, Л. Уколової, В. Федоришина, С. Філатова, О. Хоружої, В. Шульгіної та ін.

Теоретичні основи музичної освіти суб'єктів освітнього процесу закладені працями Л. Безбородової, А. Козир, О. Махайліченка, Г. Падалки, В. Смиренського, О. Хижної. Проблеми фахової підготовки майбутніх педагогів (С. Барбіна, В. Гриньова, Н. Гузій, О. Дубасенюк, В. Лозова, О. Савченко та ін.). Проте, донедавна вважалося, що фахова підготовка майбутнього вчителя музики не $\epsilon$ повною мірою сувимірною дистанційному навчанню. Сучасні дистанційні та інформаційні можливості відкривають нові горизонти якісного оновлення сутності та форм фахового навчання майбутніх учителів музики, спонукають до пошуків оптимальних організаційних оболонок розвитку їх самостійності як важливої професійно-особистісної властивості в дистанційному середовищі (Дубовий, 2019).

Формулювання цілей статті (постановка завдання). Розширити пошук засобів та умов покращення якості дистанційного навчання, вибудовувати шляхи використання в освіті інформаційних технологій під час навчання грі на музичному інструменті студентів ЗВО.

Результати дослідження. Розуміння сутності нововведень підготовки вчителя музики у ЗВО має базуватися на усвідомленні того, що XXI століття формує нові види діяльності, в основі яких лежить здатність людини обробляти нову інформацію і генерувати нове знання. Педагогу-музиканту сьогодні 


\section{С. ЧУГАЙ}

Особливості дистанційного навчання гри на музичному інструменті студентів ЗВО

потрібно чітке розуміння інноваційних процесів в освіті, які включають створення творчої атмосфери в закладах вищої освіти різних типів, культивування інтересу в науковій та педагогічній спільноті до нововведень; створення соціокультурних умов для прийняття та дії різноманітних нововведень сучасних технологій.

Саме це висуває нові вимоги до випускників педагогічних ЗВО, серед яких готовність до безперервної самоосвіти та модернізації професійної кваліфікації, до співпраці, діям у нестандартних ситуаціях; здатність до прийняття відповідальних рішень, критичному мисленню; навички роботи 3 різними джерелами інформації. Нові вимоги формулюються не так у форматі знань випускників, як у термінах способів діяльності (вміння, здібності). Таким чином, йдеться про освітні результати вищої музично-педагогічної освіти, у межах яких знання виступають необхідною, але не достатньою умовою досягнення необхідної якості професійної освіти - професійну компетентність та ії основні складові: спеціальну, професійну та базову.

У системі музично-педагогічної освіти починають превалювати методи, що забезпечують становлення самостійної творчої навчальної діяльності студентів, спрямованої на вирішення реальних професійних завдань. Визнаними підходами тут виступають орієнтоване на самостійну діяльність навчання, спрямоване на практичне засвоєння музичного матеріалу засобами дистанційного навчання. Орієнтація на світову реальність у всіх iï духовних вимірах; постає як пошук засобів та умов становлення особистості як людини культури, як творця власного життя, як індивідуальності.

Сьогодні дистанційне навчання, безумовно, $є$ сучасним методом навчання, доступним та оригінальним, що може ставити його в один ряд із класичною подачею матеріалу. Така форма навчання є перспективною і стає поширеною. Вона допомагає розвивати інтерес у галузі музичного мистецтва, розширювати дидактичний потенціал навчального процесу, підвищувати ефективність засвоєння навчального матеріалу. Інформаційні технології мотивують педагогів змінювати методи та форми своєї роботи, розвивати індивідуальні здібності студентів, оновлюють організацію освітнього процесу та посилюють міжпредметні зв'язки. Дистанційне навчання, безперечно, має право на реалізацію, але за умови не заміни, а доповнення класичної освіти.

Технології дистанційного навчання дозволяють вирішувати низку суттєвих педагогічних завдань: створення освітнього простору; формування у студентів пізнавальної самостійності та активності; розвиток критичного мислення, толерантності.

Професіоналізм педагога: теоретичні й методичні аспекти. - Вип. 16. - Слов'янськ, 2021. 
Особливості дистанційного навчання гри на музичному інструменті студентів ЗВО

Дистанційне навчання грунтується на використанні сучасних інформаційних та телекомунікаційних технологій, що дозволяють здійснювати навчання на відстані без безпосереднього контакту між викладачем та студентом. Технологія дистанційного навчання полягає в тому, що навчання та контроль засвоєння матеріалу відбувається за допомогою комп'ютерної мережі, використовуючи як синхронне, так і асинхронне навчання (Кисельов, 2020).

Синхронне навчання передбачає спілкування у режимі реального часу. При асинхронній методиці відповідальність доручається студентові: самонавчання, вибір зручного темпу роботи. Найбільшої ефективності при дистанційному навчанні можна досягти при використанні змішаних методик, тобто, як синхронної, так і з асинхронної методики навчання.

Актуальність дистанційного навчання обумовлена факторами, серед яких можна назвати: потреба в інтерактивній взаємодії студентів та викладачів; забезпечення можливості продовження освітнього процесу за умов запровадження карантину; при заочній формі навчання; під час роботи 3 обдарованими студентами (індивідуальні додаткові завдання підвищеного рівня); під час підготовки до конкурсів, фестивалів.

Зазначимо, що музично-педагогічний процес - дуже консервативний. Це зумовлено тим, що методика викладання, особливо виконавських дисциплін, складалася і вивірялася протягом сотень років. Традиції та досвід авторитетних педагогів, зафіксовані в авторських методиках, визначають стійкість форм та методів навчання, репертуар, взаємодію між викладачем та студентом. Йдеться про певну стійкість і наступність традицій, заснованих на емпірично-зумовлених методах роботи, особливо це стосується представників виконавського напряму музичної діяльності.

Дистанційне навчання, тобто взаємодія викладача та студентів між собою на відстані, відбиває всі притаманні освітньому процесу компоненти та реалізується специфічними засобами ІКТ технологій або іншими засобами, що передбачають інтерактивність. Проведення дистанційного заняття з предметів виконавського спрямування (баян, акордеон, фортепіано, вокал та ін.) можливе такими методами: онлайн-урок; перегляд відеозапису виконання студента; відеоурок; відеодзвінок (Дорош, 2021).

Онлайн-урок - урок викладача та студента, які знаходяться одночасно кожен за своїм інструментом, і в режимі реального часу викладач може зробити зауваження та зупинити гру студента у будь-який момент. Але цей спосіб онлайн-уроку має свої недоліки: відставання та спотворення звуку, що стають критичними для можливості оцінки звукового результату викладачем. Звук 


\section{С. ЧУГАЙ}

Особливості дистанційного навчання гри на музичному інструменті студентів ЗВО

пливе, переривається і має тембрально мало спільного з оригіналом. Не важливо, яку використовувати платформу для зв'язку - спотворення звуку присутні скрізь.

Однак, такий спосіб дистанційного навчання - єдиноможливий для проведення уроку зі студентами початківцями 3 двох причин: по-перше, репертуар для початкового етапу навчання простий, завдання ставляться конкретні, невисока швидкість виконання п'єси, а володіння звуковими фарбами знаходиться на базовому рівні, разом із тим студенту набагато звичніше й комфортніше перебувати у прямому контакті з викладачем, який вказує йому на помилки тут i зараз i словесно допомагає їх виправити. По-друге, приклад виконання музичного твору викладачем на інструменті, де студент може візуально контролювати та коригувати правильну посадку за інструментом, постановку ігрового апарату та застосування різних штрихів.

Перегляд відеозапису виконавця з наступним потактовим (письмовим або усним) розбором та коментарями викладача. Спосіб відеозапису з коментарями більш інформативний щодо запису та відтворення звуку, саме тому відеозаписи застосовуються у відборах на мистецькі конкурси.

Цей режим роботи має незаперечні переваги: поки здобувач зробить запис, який задовольнить його власні вимоги, він відразу проводить роботу над якістю свого виконання та підвищує рівень самоконтролю; викладач має можливість ретельніше вслухатися у деталі гри виконавця, повторно прослуховувати окремі місця, ставити запис на паузу, щоб сформулювати зауваження, не перериваючи процес виконання; студент має письмові коментарі викладача, iз якими можна звірятись постійно, може перенести коментарі у вигляді позначок олівцем у свої ноти. На завершальному етапі роботи над твором викладач, може використовувати усні коментарі телефоном, а також надсилати записані відео 3 показом виконання окремих місць музичного твору, так само як це відбувається на звичайному уроці.

Дистанційне заняття уроку 3 вокалу, як i уроки за інструментом, проводяться на різних сервісах (Skype, Zoom, GoogleMeet, Messenger та ін.). Більшість студентства користуються планшетами, телефонами та ін., які встановлюють праворуч від інструменту, або прямо перед собою. Під час співу вони стоять як перед камерою, так і в профіль, для того, щоб було краще видно положення голови та корпусу тіла під час співу та гри за інструментом. Для правильної техніки співочого дихання та зовнішнього візуального естетичного сприйняття вокаліста, основне положення корпусу та голови має бути наступним: голову тримати прямо, вільно, не опускаючи їі вниз і не закидати назад; стояти твердо на обох ногах, рівномірно розподіляти центр ваги тіла;

Професіоналізм педагога: теоретичні й методичні аспекти. - Вип. 16. - Слов’янськ, 2021. 
Особливості дистанційного навчання гри на музичному інструменті студентів ЗВО

корпус тримати прямо без напруги, а також коригувати посадку за інструментом, постановку ігрового апарату та застосування різних штрихів.

Зауважимо, що на заняттях із дистанційного навчання легше студентам, які вже знайомі з музичною грамотою, вони можуть безпосередньо самостійно розібрати та прочитати з аркуша нотний матеріал. Таке навчання стимулює їх до самостійного читання нот та вивчення знаків у музичному тексті, мотивує до подолання труднощів, які виникають у процесі роботи. Таким чином, особливість онлайн-занять полягає у тому, що у роботі зі здобувачами вищої освіти можна відпрацьовувати вже розібраний музичний текст. Метод застосування відео та аудіо записів на дистанційних заняттях, зручний для самоконтролю: переглядаючи та прослуховуючи свої записи, студенти аналізують власне виконання та надалі працюють над помилками. Викладач коментує відео або аудіо запис, вказує на важливі моменти самостійної роботи студента.

Відзначимо, що на початкових етапах дистанційного навчання помітно знижується темп вивчення музичних творів та засвоєння знань. Нестача безпосереднього спілкування «студент - викладач», помітно позначається на якості результату. Тому на дистанційних заняттях важливо, щоб студент добре бачив на екрані обличчя, руки, пальці викладача (залежно від предмета викладання: вокал чи гра на музичному інструменті). Так студент зможе уважно спостерігати за артикуляцією, роботою співочого апарату або посадкою за інструментом, постановкою рук й аплікатури. Освітлення має бути спрямоване на виконавця, у кадрі не повинно бути предметів, які відвертають увагу. Говорити потрібно спокійно, неквапливо. Перед проведенням заняття необхідно уточнити, чи добре студент чує викладача, чи чітке зображення. Під час проведення дистанційного заняття говорити доводиться більше i набагато голосніше, це призводить до перенавантажень голосових зв’язок. Тому, знання механіки звукоутворення та розуміння методичних прийомів забезпечить виконавця від перенапруги та втоми зв’язок.

Під час уроків гри на інструменті (баян, акордеон) доцільно використовувати такі форми роботи: голосові та текстові повідомлення; аудіо та відео записи; відеодзвінок.

За розкладом або в призначений час, викладач здійснює відеодзвінок, який дає можливість викладачеві проаналізувати рівень засвоєння студентом матеріалу (переклади творів, що розучуються, заздалегідь надсилаються викладачем), відпрацювати недоліки виконання, розібрати складні місця у музичному творі. У форматі відеодзвінка викладач слідкує за корпусом виконавця та правильністю його посадки за інструментом. 


\section{С. ЧУГАЙ}

Особливості дистанційного навчання гри на музичному інструменті студентів 3ВО

Поширеною формою дистанційного навчання є відеоурок. Викладач може заздалегідь записати урок у форматі відео. Така форма навчання зручна при подачі теоретичного матеріалу, де даються чіткі формулювання правил, розшифровуються значення музичних термінів та знаків. Відеоурок дає можливість викладачеві наочно показувати студенту ритмічний малюнок твору, техніку роботи окремо правою та лівою рукою, виконавську майстерність. Цей спосіб зручний тим, що такий урок можна переглядати декілька разів.

Перевірка та коригування самостійної роботи студента здійснюється через відеозвіт. Студент надсилає викладачеві відео з виконаним завданням, за аналізом цього відео викладач дає рекомендації. Така форма роботи - чудовий спосіб зворотного зв'язку від студента до викладача.

Усі перераховані вище форми роботи ефективні, якщо студент має особистий музичний інструмент (баян, акордеон). В умовах офлайн навчання студенти, які не мають інструменту, займаються у стінах ЗВО. Найважливішим етапом переходу на дистанційне навчання $є$ придбання інструменту.

При дистанційному форматі навчання $є$ позитивні аспекти, які визначилися в процесі роботи: технологічність; свобода та гнучкість; відкритість та доступність; психологічний затишок. Використання сучасних програмних технічних засобів робить електронну освіту ефективнішою, а інформацію, представлену візуально, динамічною, яскравою, що запам'ятовується. Вільний доступ швидкісного інтернету робить дистанційне навчання цікавим та повноцінним. Можливість навчатися, не виходячи з дому. Займатися можливо в зручний час та поєднувати роботу з навчанням. $€$ індивідуальний темп вивчення курсу, повернення до окремих тем вивченого матеріалу. Можливість обрати кваліфікованих викладачів та навчання за сучасними технологіями. Дистанційне навчання знімає проблему, а також питання суб'єктивного оцінювання та психологічного впливу.

На жаль, існує і низка недоліків під час дистанційного навчання у сфері музичної освіти: спотворення звуку по відео зв'язку; нестача фізичного контакту педагог - студент; обмеженість контролю над технікою виконання з різних ракурсів; проблеми 3 диригуванням; відсутність у студентів мотивації, самоорганізації, працьовитості, певного базового рівня; немає традиційних академічних прослуховувань, звітних концертів як підсумкового результату; неможливість підвищити рівень виконавської майстерності (Харьков, 2018).

Якщо на індивідуальних заняттях із музичного мистецтва вдається мінімізувати негативний вплив дистанційності, то 3 груповими формами взаємодії все набагато складніше. В аудиторії можна працювати над тим, щоб звуки зливалися в музику, працювати в ансамблі. В умовах спільної гри на

Професіоналізм педагога: теоретичні й методичні аспекти. - Вип. 16. - Слов'янськ, 2021. 


\section{С. ЧУГАЙ}

Особливості дистанційного навчання гри на музичному інструменті студентів ЗВО

музичних інструментах чи спільного вокального виконання студенти можуть чути, як звуки збираються разом, в одне гармонійне поліфонічне звучання. Під час онлайн-заняття вони чують лише свої власні звуки у неспотвореному вигляді, але це може бути i позитивним моментом: студенти працюють над індивідуальними навичками - вилучення звуку, вдосконалення звучання голосу, звучання інструменту. Таким чином, дистанційне навчання у сфері музичної освіти це вимушений захід, покликаний здебільшого зберегти дисципліну й досягнутий раніше рівень, воно не має того необхідного ступеня емоційного контакту між студентом та викладачем, без якого неможливий розвиток творчих здібностей і не може бути застосоване як замінник офлайн навчання.

Урок з педагогом-професіоналом - це завжди можливість «побачити» «невидиме», зрозуміти недоступне, почути нову якість звуку, відчути широкі виконавські можливості баяну/акордеону, відкрити для себе сенс творчого процесу та зрозуміти важливість самостійної роботи. Сам педагог і заняття з ним - важливі чинники самостійної роботи, що дозволяють іiі активізувати. Педагог $\epsilon$ індивідуальним носієм національних традицій виконавської школи та кожне систематичне спілкування з ним дає не лише певний перелік умінь та навичок, а несе загальний естетичний, мистецький розвиток у своїй професії та виступає зразком високого виконавського мистецтва.

Серед чинників активізації самостійної роботи слід ураховувати внутрішній стрижень характеру. Здатність до самоорганізації, темперамент, характер - важливі складові, які акумулює в собі майбутній професійний музикант: вміння бути зібраним, уважним та з високий рівень креативності.

Вищезазначений ряд є своєрідною основою активізації самостійної роботи. Внутрішній світ баяніста/акордеоніста, його психологічний настрій, вольові якості - значний ресурс для активізації самостійної роботи. Процеси рефлексії, самопізнання, самосвідомості, самооцінки безпосередньо впливають на таку активізацію. Для кожного інструменталіста, велике значення має як розвиток слухомоторного потенціалу, так і мистецтво його застосування в умовах психологічної стійкості, артикуляційно-штрихового розмаїття, в контексті вирішення завдань інтонаційної виразності, стилістичної коректності, досягнення художньо-образної глибини музичних творів й стабільності виконання.

Педагог може направити студента, вказати шлях досягнення мети, позначити засоби ії втілення. Але, остаточне рішення, весь процес, деталізація, характер втілення ідеї музичного твору лежать у зоні самостійної роботи здобувачів вищої музичної освіти. Звідси випливає, що завдання викладача полягає у тому, щоб наблизити студента до глибокого розуміння і справді 


\section{С. ЧУГАЙ}

Особливості дистанційного навчання гри на музичному інструменті студентів ЗВО

художнього виконання музики, а й навчити його продуктивно самостійно працювати.

Висновки 3 дослідження і перспективи подальших розвідок у цьому напрямі. Отже, найважливішим компонентом у процесі засвоєння знань виступають не предметні знання, а сам студент як суб’єкт своєї діяльності. Дистанційне навчання у музичній освіті дає змогу організувати продуктивну самостійну роботу студента 3 навчальної дисципліни, сприяє формуванню професійних компетентностей, сприяє формуванню мобільності, вмінню шукати й опановувати нові знання; надає нову якість навчання, забезпечуючи постійний доступ до інформації в будь-який момент часу; сприяє формуванню гнучкого навчання на основі нових можливостей IKT із представлення навчальних та нотних текстів, графічних матеріалів i проведення різних форм відеоспілкування, дає змогу забезпечити ефективний зворотний зв’язок.

\section{СПИСОК ВИКОРИСТАНИХ ДЖЕРЕЛ}

1. Дорош, Т. Л. (2021). Дистанціийний освітній процес у системі підготовки майбутніх учителів музичного мистецтвва. Харків, Україна: ФОП Панов А. М.

2. Дубовий, 3. С. (2019). Формування самостійності майбутніх учителів музики у процесі дистаниійного навчання. (Дис. канд. пед. наук). Київ, Україна: Національний педагогічний університет імені М. П. Драгоманова.

3. Закон України про освіту. № 2145-19. (2017, 5 вересня). Взято 3 http://zakon2.rada.gov.ua/laws/show/2145-19.

4. Кисельо, Н. Р. (2020). Синхронне та асинхронне навчання - невід'ємні складові дистанційної освіти. Матеріали V Міжнародної науково-практичної конференції «Сучасна наука: проблеми і перспективи» (С. 17-18). Київ, Україна: МЦНіД.

5. Положення про дистанційне навчання. № 466. (2013, 25 квітня). Взято 3 https://zakon.rada.gov.ua/laws/show/z0703-13.

6. Смаковський, Ю. В. (2020). Професійна підготовка майбутніх учителів музичного мистецтва в умовах дистанційного навчання. Науковий часопис НПУ імені М. П. Драгоманова. Серія 5. Педагогічні науки: реалії та перспективи, Вип. 76, 156-159. DOI: https://doi.org/10.31392/NPU-nc.series5.2020.76.34.

7. Харьков, Е. В. (2018). Дистанционное музыкальное образование: проблемы и перспективы. Взято 3 https://unjugandshi.hmansy.muzkult.ru/media/2018/09/19/1217081970/Statya_kharkov_E.V.pdf.

8. Havrilova, L. H., Ishutina, O. Y., Zamorotska, V. V., \& Kassim, D. A. (2019). Distance learning courses in developing future music teachers' instrumental performance competence. in: Kiv, A.E., Soloviev, V.N. (eds.). Proceedings of the 6th Workshop on Cloud Technologies in Education (CTE 2018), Kryvyi Rih. 429-442.

\section{FEATURES OF DISTANCE LEARNING ON PLAYING THE MUSICAL INSTRUMENT OF UNIVERSITY STUDENTS}

\section{Serhii Chuhai}

Senior Lecturer of Music and Choreography Department, SHEE "Donbas State Pedagogical University" 


\title{
С. ЧУГАЙ
}

Особливості дистанційного навчання гри на музичному інструменті студентів ЗВО

\author{
Sloviansk Ukraine \\ ORCID ID 0000-0003-4294-888X \\ sergeichugay@gmail.com
}

\begin{abstract}
The article considers new possibilities and approaches in the organization of distance learning, methods of distance learning and the effectiveness of their use in the process of playing a musical instrument. Possibilities of distance learning in the system of professional training are highlighted. Theoretical aspects of distance education development are revealed. Features of use of remote technologies which are a part of practice of modern educational process are considered.

Forms, methods of work used in distance learning are determined. An analysis of the advantages and disadvantages of distance learning while playing a musical instrument. The problem of formation of independence of university students during distance learning to play a musical instrument is investigated. The significance of students' independence formation in the process of professional training is analyzed.

It is determined that the independence of students is a complex professional and personal property, which arises on the basis of mastering special (artistic) and psychological and pedagogical knowledge, is embodied in a wide range of practical skills, encourages active action. The organizational and pedagogical conditions for the formation of students' independence in the process of distance learning are substantiated.

It is concluded that distance learning in music education makes it possible to organize productive independent work of a student in the discipline, promotes the formation of professional competencies, promotes the formation of mobility, the ability to seek and master new knowledge; provides a new quality of training, providing constant access to information at any time; promotes the formation of flexible learning based on new ICT opportunities for the presentation of educational and musical texts, graphics and various forms of video communication, allows for effective feedback.

Key words: distance learning; music learning; distance technologies; musical art; musical instrument; independent work; student; higher education seeker.
\end{abstract}

\section{REFERENCES}

1. Dorosh, T. L. (2021). Dystantsiinyi osvitnii protses u systemi pidhotovky maibutnikh uchyteliv muzychnoho mystetstva [Distant educational process in the system of training of maybutny teachers of musical art]. Kharkiv, Ukraine: FOP Panov A. M. [in Ukrainian].

2. Dubovyi, Z. S. (2019). Formuvannia samostiinosti maibutnikh uchyteliv muzyky u protsesi dystantsiinoho navchannia [Formation of future music teachers' self-dependence during the distance learning process]. (PhD dissertation). Kyiv, Ukraine: Natsionalnyi pedahohichnyi universytet imeni M. P. Drahomanova. [in Ukrainian].

3. Law of Ukraine on education. № 2145-19. (2017, September 5). Retrieved from http://zakon2.rada.gov.ua/laws/sh ow/2145-19. [in Ukrainian].

4. Kyselo, N. R. (2020). Synkhronne ta asynkhronne navchannia - nevidiemni skladovi dystantsiinoi osvity [Synchronous and asynchronous navchannya - there are no warehouses for remote coverage]. Proceedings from V Mizhnarodnoi naukovo-praktychnoi konferentsii «Suchasna nauka: problemy i perspektyvy». (Pp. 17-18). Kyiv, Ukraine: MTsNiD. [in Ukrainian].

5. Provisions about distance navigation. № 466. (2013, April 25). Retrieved from https://zakon.rada.gov.ua/laws/show/z0703-13. [in Ukrainian].

6. Smakovskyi, Yu. V. (2020). Profesiina pidhotovka maibutnikh uchyteliv muzychnoho mystetstva $\mathrm{v}$ umovakh dystantsiinoho navchannia [Professional training of future teachers of music art in the conditions of distance learning]. Naukovyi chasopys NPU imeni M. P. Drahomanova. Seriia 5. Pedahohichni nauky: realii ta perspektyvy, Vol. 76, 156-159. DOI: https://doi.org/10.31392/NPUnc.series5.2020.76.34. [in Ukrainian].

() ДВНЗ «Донбаський державний педагогічний університет» 
Особливості дистанційного навчання гри на музичному інструменті студентів 3ВО

7. Kharkov. E. V. (2018). Distantsionnoe muzykalnoe obrazovanie: problemy i perspektivy [Distance music education: problems and prospects]. Retrieved from https://unjugandshi.hmansy.muzkult.ru/media/2018/09/19/1217081970/Statya_kharkov_E.V.pdf. [in Russian].

8. Havrilova, L. H., Ishutina, O. Y., Zamorotska, V. V., \& Kassim, D. A. (2019). Distance learning courses in developing future music teachers' instrumental performance competence. in: kiv, a.e., soloviev, v.n. (eds.). Proceedings of the 6th Workshop on Cloud Technologies in Education (CTE 2018), Kryvyi Rih. 429-442. [in English].

Матеріали надійшли до редакції 10.10.2021 p. 